\title{
Reading Comprehension in Face-to-Face and Web-Based Modalities: Graduate Students' Use of Reading and Language Learning Strategies in EFL'.
}

\author{
Comprensión de lectura en las modalidades presencial \\ y en la web: lectura y Estrategias de Aprendizaje \\ del Lenguaje usadas por estudiantes de posgrados \\ aprendices de inglés como lengua extranjera.
}

Fabio Alberto Arismendi Gómez, Doris Colorado López, Luisa Fernanda Grajales Marin Professors, School of Languages. Universidad de Antioquia Medellín, Colombia

Received 18-Oct-11/ Accepted 8-Nov-11

E-mail: fabioarismendi@yahoo.com

colorado.doris@gmail.com

luisafer.grajalesm@gmail.com

\begin{abstract}
Few studies in Colombia have explored and compared students' reading comprehension processes in EFL, in different modalities of instruction. This article reports on some findings of a larger study in which two groups of graduate Law students took a reading comprehension course in English, delivered in two different modalities of instruction: face-to-face and web-based. Both courses were served by an English teacher from the School of Languages at Universidad de Antioquia. The data gathered from class observations, in-depth interviews, questionnaires, tests, the teacher's journal and data records in the platform provided insights about the students' use of reading and language learning strategies in both modalities. Findings suggest that students applied the reading strategies explicitly taught during the courses and some language learning strategies for which they did not receive any instruction.
\end{abstract}

Key words: face-to-face instruction, web-based instruction, teaching of reading comprehension in EFL, reading strategies, language learning strategies.

\section{Resumen}

Pocos estudios en Colombia han explorado y comparado los procesos de comprensión de lectura en inglés de los estudiantes, en diferentes modalidades de instrucción. En este artículo se presentan algunos hallazgos de un estudio en el cual dos grupos de estudiantes de posgrado de la Facultad de Derecho participaron en un curso de competencia lectora en inglés, ofrecido en dos modalidades diferentes: presencial y virtual. Ambos cursos fueron servidos por un profesor de inglés de la Escuela de Idiomas de la Universidad de Antioquia. Los datos recogidos de las observaciones de clase, de las entrevistas a profundidad, de los cuestionarios, de los exámenes, del diario del profesor y los datos grabados en la plataforma permitieron comprender el uso de estrategias de lectura y de aprendizaje en ambas modalidades. Los hallazgos muestran que los estudiantes aplicaron las estrategias de lectura enseñadas explícitamente en el curso y algunas estrategias de aprendizaje para las cuales no hubo instrucción explícita.

Palabras claves: presencialidad, enseñanza virtual, enseñanza de la competencia lectora en L2, estrategias de comprensión de lectura, estrategias de aprendizaje.

1 This article reports some findings of the Project: Effects of the modalities of instruction face-to-face and web-based distant in Reading comprehension in English in the graduate programs at Universidad de Antioquia funded by Comité para el Desarrollo de la Investigación CODI and carried out between January 2009 and September 2011. 


\section{Introduction}

The introduction of new information and communication technologies (ICTs) in foreign language teaching and learning has grown considerably in recent years in Colombia. Many public and private universities have attempted to integrate ICTs in the language courses they offer. Berdugo and Pedraza (2008) highlight the current tendency amongst institutions such as Universidad de Antioquia, Universidad Nacional and Universidad del Valle to adopt virtual learning environments like Moodle and Blackboard for the teaching of foreign languages. Despite this, there is little evidence that online platforms are being used in Colombia as the sole mode of instruction, especially for the teaching of reading comprehension in English. Additionally, there has been little analysis of the effects of web-based instruction on students' EFL learning processes. These two factors prompted a group of researchers from the group EALE (Enseñanza y Aprendizaje de Lenguas Extranjeras) at Universidad de Antioquia to investigate the effects of differing modes of delivery of reading comprehension courses on students. In order to do this, we created the same reading comprehension course in both web-based and face-to-face modalities and evaluated the implementation of both courses and the effects these modalities had on students. Partial results of this study were published by Muñoz and Gonzalez (2010) who reported the emergence of new roles for foreign language teachers working in web-based courses, namely: technical knowledge expert, immediate feedback provider, interlocutor in non-traditional studentteacher communication, time-management advisor and constant motivator. Their discussion falls within one of the broader categories that emerged during the final process of categorization of the data: new roles for web-based teachers. The other categories identified were: interactions, perceptions and beliefs about learning to read in English in a web-based environment, and the students' learning processes regarding the use of reading and learning strategies. This article focuses on this final category.

We analyse the reading and learning strategies students used in both modalities in order to describe their learning processes. We start with a literature review of the main concepts. We then describe the methodology of the study and finally, we present and discuss the main findings from which we draw some conclusions.

\section{Literature review}

\section{Web-based education}

The term web-based education comes from what has traditionally been called distance and virtual learning. Today the term distance education (Sampson, 2003; García, 1999) is mainly used to describe courses where most of the interactions between teachers and students take place electronically through audio, video, chat, e-mail, videoconferences or internet platforms. Facundo (2004) describes virtual education as different processes and educative services which take place through the application of technologies that use binary numeric language to simulate the reality without the space limitations intrinsic to physical environments. Therefore, when we use the term web-based education we refer to academic programs delivered by electronic means which allow them to be studied in a space different to that in which they are taught in faceto-face pedagogic interactions.

Keegan (1990, in Sampson, 2003) identifies the following basic elements of web-based education:

\footnotetext{
The separation of teacher and learner; the influence of an educational organization; the use of technical media (usually print) to unite the teacher and learner and to carry educational content; the provision
} 
of two-way communication so that the student may benefit from or even initiate dialogue; and the possibility of occasional meetings for both didactic and socialization purposes" (p.104).

Students who access this kind of education thus constitute a very particular population since they do not want to, they are not able to, or choose not to participate in face-to-face learning. As a result they opt for this modality due to its convenience and flexibility.

\section{Face-to-face education}

Face-to-face education is essentially offered in physical spaces (classrooms, laboratories, libraries and computer rooms, amongst others) where the teacher has direct contact with the students. Usually, he establishes objectives, plans activities, prepares resources, delivers the session and assesses students. Verbal communication is integral to this modality thus students are provided with a great many opportunities to develop their oral communication skills in the classroom. According to Galindo (2002), the main characteristics of face-to-face education are the presence of the teacher in front of the students in a room ensuring greater interaction, the time and location are defined, the content of the course consists of notes prepared by the teacher to present and discuss in class and the theoretical basis of instruction can be behaviourism, cognitivism, constructivism or a combination of these.

\section{Reading comprehension}

\section{Reading process}

Grabe (2007) states that "there really is no single notion of reading, but rather four or five different skills that we all tend to call reading" (p.13) and he continues affirming that "when viewed in terms of the set of processes involved, reading becomes a unified process that is adjusted flexibly in response to reader purpose, reader proficiency level, and possible contextual constrains" (p. 13). Reading is a complex combination of processes. It is a rapid, efficient, comprehending, interactive, strategic, flexible, purposeful, evaluative, learning, and linguistic process. (Grabe, 2007, p. 14). Grabe and Stoller (2002, p.13) classify purposes for reading under seven main headings: reading to search for simple information, reading to skim quickly, reading to learn from texts, reading to integrate information, write and critique texts, and reading for general comprehension. The same authors present three main sets of differences in L1 and L2 reading contexts that may affect the reading process and thus instruction: linguistic and processing differences, individual and experiential differences, and socio-cultural and institutional differences.

\section{Models of reading}

Aebersold and Field (1997, p.18) present three main models of how reading occurs: the bottom-up theory which "argues that the reader constructs the text from the smallest units (letters to words to phrases to sentences, etc.)" and that this process becomes automatic for readers. Reading is the same as decoding. In The topdown theory, "readers fit the text into knowledge (cultural, syntactic, linguistic, historical) they already possess, then check back when new or unexpected information appears". The interactive school, which is the position we adopt because it fits with the direct training on reading strategies done in the course, asserts that "both top-down and bottom-up processes are occurring, either alternately or at the same time ... depending on the type of text as well as on the reader's background knowledge, language proficiency level, motivation, strategy use, and culturally shaped beliefs about reading." As reading is an interactive process, readers use both top-down and bottom-up strategies to comprehend a text. 
"The bottom-up strategies provide a linear or sentence by sentence building of comprehension. Top-down approaches, such as discourse-level strategies, aid readers' comprehension of largest pieces of text, such as a paragraph or section. They help readers see how an individual sentence or a group of sentences contribute to that larger meaning (a topdown approach). Efficient readers employ both types, moving from one to the other as they read." (Aebersold and Field, p. 97)

Based on a review of current research, Grabe and Stoller (2002) mention 4 types of models of reading: the psycholinguistic guessing model, the interactive compensatory model, word recognition models and the simple view of reading. The psycholinguistic guessing model (a top-down oriented model) "portrays reading comprehension as a universally, applicable iterative process of (a) hypothesising, (b) sampling and (c) confirming information based on background knowledge, expectations about the text, a sampling of surface features of the text and context information from the text"(p. 34). This first model relates to constructivist and transactional models of reading which argue that "readers are able to carry out basic reading comprehension rather than explaining how these processes can operate of how they develop" (p. 34). The interactive compensatory model presumes that "readers develop efficient reading processes" (p. 35) which interact and operate independently depending on their automaticity. Word recognition models do not consider higherlevel comprehension processes, and are related to connectionist bottom-up orientated theories. Finally, there is the simple view of reading model which argues that "reading comprehension is composed of a combination of word recognition abilities and general comprehension abilities" (p. 36)
Recent studies on reading comprehension show that ICTs have given birth to what Leu et al. (2008) and Leu et al. (2004) call new literacies. These authors highlight that reading online has changed the traditional view of print reading and that a new model should be developed considering these technologies at its basis (Leu et al., 2004). Furthermore, they draw attention to the fact that "the emergence of new online reading comprehension skills has profound consequences for instruction as reading has moved from page to screen" (Leu et al. 2008, p.321) implying new roles for the instructor (Muñoz and Gonzalez, 2010). They also consider that "proficient readers offline are not always proficient readers online" (Coiro, 2007 cited in Leu et al. 2008, p.321). Leu et al. (2008) present a set of aspects in which new literacies differ from traditional print reading and state that they demand new skills for readers because in addition to considering purpose, task and context, new literacies become a "process of self-directed text construction" (p.323). Thus, the overlap of print reading and new literacies enrich the processes of reading but also makes understanding reading in the $21^{\text {st }}$ century more complicated (Leu et al., 2008).

\section{Reading and language learning strategies}

Grabe E Stoller (2002, p. 17) understand the strategies as "abilities that are potentially open to conscious reflection and use". Several authors have highlighted the importance of teaching reading strategies to facilitate reading comprehension in a foreign language. Brown (1994) considers that the reading process in a foreign language is a matter of developing effective and appropriate strategies for comprehension. As reading strategies are selected, controlled and applied consciously by readers, they need to develop their metacognitive awareness or metacognitive skills. The definition of metacognitive awareness is "that the reader can devote attentional resources to determine whether 
or not comprehension is occurring, the reading goals are being met, and linguistic resources can assist comprehension" (Grabe, 2007, p. 52). Metacognition is therefore very important in reading because it encompasses the knowledge the reader possesses of the different strategies he can use and the control and regulation of his actions depending on his purpose for reading a text. Metacognitive and cognitive strategies in L2 reading are rarely developed by the reader alone, he needs explicit instruction and training from the teacher and according to McTavish (2008) "teachers need to direct attention more explicitly to the process of comprehension while students are reading, rather than to the processing of text after students have completed their reading" (cited in López \& Giraldo 2011, p. 50).

Reading strategies are complemented by language learning strategies. Several authors have provided definitions and taxonomies for learning strategies (O'Malley and Chamot, 1990;
Oxford, 1990). We will stick to the definition proposed by Oxford (1990, p. 1) as "steps taken by students to enhance their own learning [which] are especially important for language learning because they are tools for active, self-directed involvement, which is essential for developing communicative competence". Even if the reading comprehension course does not aim to develop such communicative competence, the use of language learning strategies as stated by Oxford (1990) helps improve students' self-confidence and this reading strategies approach helps the learner to apply a learning strategy to solve a difficulty when trying to understand a text. The learner relies on textual elements and his/her background knowledge to interact with the text. The taxonomy we will use for language learning strategies is that of Oxford (1990) who divides them into two main categories: direct and indirect, as shown in table 1 . We will give a more complete definition of them in the discussion of the findings.

Table No. 1. Oxford's taxonomy for language learning strategies (1990)

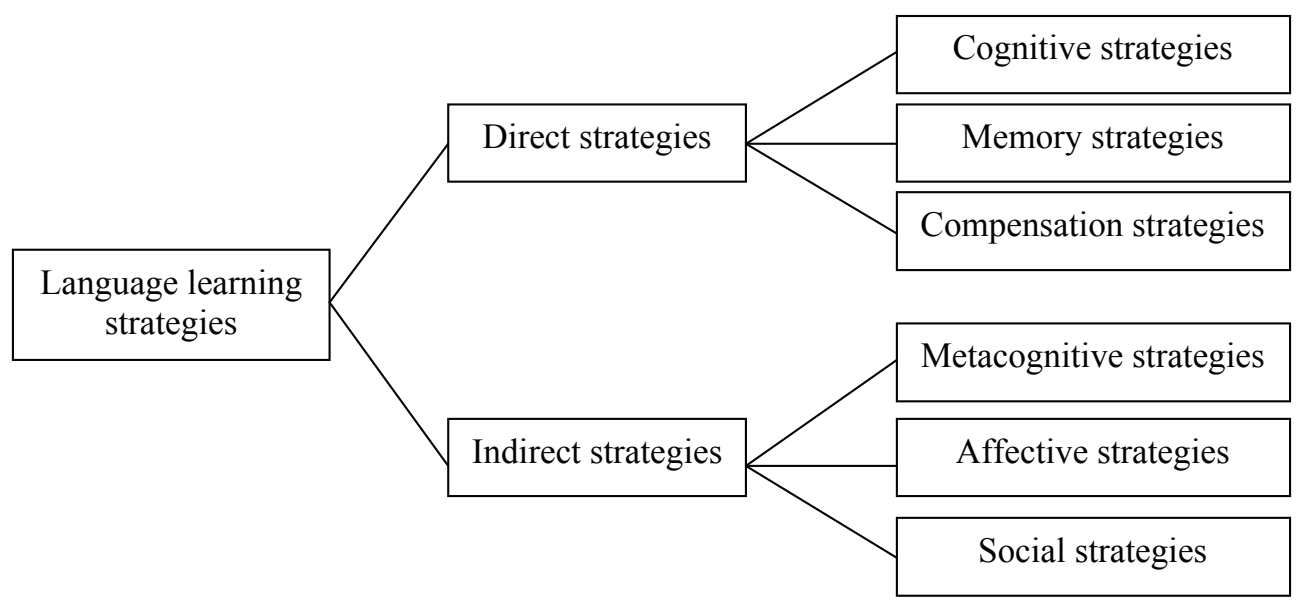

\section{Context of the study}

This study was conducted at Universidad de Antioquia, one of the biggest public universities in
Colombia with more than 30,000 undergraduate students and about 2000 graduates. The language of instruction is Spanish but students are required to certify a minimum competence in a foreign 
language. Graduate students are required to attend a 120 hour reading comprehension course in English, or in French, before the end of the first term of their academic program. Alternatively they have the option to certify their reading comprehension in a foreign language by taking an exam that may be in English, French, German, Italian or Portuguese. Before the end of their academic program, they are also required to certify listening comprehension in a foreign language. These exams and courses are delivered by the "Sección Servicios" of the School of Languages. The 120 hour reading comprehension course offered for the graduate students focuses on intensive reading which helps readers develop strategies and abilities useful for improving the reading comprehension process in a foreign language so that they can access a range of materials in English. It concentrates on the explicit teaching of grammatical forms, discourse markers, and other structures that need to be studied in the courses and that may pose some problems for students (Anderson, 1999). Aebersold and Field (1997) and Nuttall (1996) state that intensive reading purports to give readers the necessary tools to comprehend a text. Alyousef (2005) identifies intensive reading as an activity whose objective is to have students explore, by means of strategies, the meaning of a text and at the same time get familiarised with the written structure of the language.

This course is divided into five different units organised as follows:

Table No.2. Organisation of the course

\begin{tabular}{|c|l|l|}
\hline UNIT & \multicolumn{1}{|c|}{ NAME } & \multicolumn{1}{c|}{ MAIN TOPICS } \\
\hline 1 & $\begin{array}{l}\text { The words and their } \\
\text { meaning }\end{array}$ & $\begin{array}{l}\text { Use of the dictionary, parts of speech, } \\
\text { cognates, affixes and word meaning in } \\
\text { context }\end{array}$ \\
\hline 2 & Reading strategies & $\begin{array}{l}\text { Prediction, skimming, scanning and graph } \\
\text { interpretation }\end{array}$ \\
\hline 3 & $\begin{array}{l}\text { Development of reading } \\
\text { skills }\end{array}$ & $\begin{array}{l}\text { Sentence structure, topic, identification of } \\
\text { main idea and referents }\end{array}$ \\
\hline 4 & $\begin{array}{l}\text { Methods of organization of } \\
\text { texts }\end{array}$ & $\begin{array}{l}\text { Cause and effect, comparison and } \\
\text { contrasts, description, narration, } \\
\text { argumentation, and classification and } \\
\text { categorization }\end{array}$ \\
\hline 5 & Critical reading & Facts and opinions, tone and arguments \\
\hline
\end{tabular}

\section{Methodology}

The study

The study reported in this article derives from a major study on the effects of web-based and face-to-face instruction modalities in the reading comprehension of graduate students. The minor study we report focuses on the use of reading and language learning strategies used by a group of graduate EFL learners. This small scale study uses statistical analysis and descriptive analysis to report the findings. The overarching research question that guided the major study was: what are the effects of the web-based and face-to-face instruction modalities in reading comprehension in English in graduate students at the Universidad de Antioquia? 
This article takes as its subject one of the objectives of the major study, to explore the reading and language learning strategies used by graduate EFL learners at Universidad de Antioquia, which we explore in this article. We followed the methodology of an exploratory case study (Merriam, 1998; Creswell, 2007; Yin, 2003), an approach which afforded us the opportunity to merge the personal insights of both students and the teacher with the data recorded in the platform.

\section{Learning content-management system}

The virtual learning environment for the course was MOODLE (Modular Object-Oriented Dynamic Learning Environment) which is the platform used in the university for this type of course. According to Ardila and Bedoya $(2006,188)$ this platform was developed by the Australian professor Martin Dougiamas at the beginning of the 1990s and has as philosophical and pedagogical basis the socio-constructivist model. These authors highlight some of the characteristics of the platform which have resulted in its extensive use around the world, among them: it has a simple, user-friendly and efficient interface; it offers a series of activities for the courses: homework, dialogue, chat, forum, wikis and glossary, among others; it creates a complete register of user activity; it allows access to reports of the activities of every student with graphics and details of the work they have done in the platform; and, it integrates e-mail.

\section{Participants}

The School of Languages offered two reading comprehension courses in English to graduate students at the School of Law in order to carry out this research. The same teacher taught both courses and they had exactly the same content. The first course delivered was the web-based one where 38 graduate students (13 men and 25 women) participated. They were between 23 and 49 years old. The face-to-face course started after this and had 27 students (10 men and 17 women). They were between 20 and 51 years old. All the students were registered in the first term of different specialisations in Law (Social Security, Constitutional Law, Administrative Law, Process Law and Family Law). During the study eight students dropped out of the web-based course and one of the face-to-face course, all because they obtained the necessary score in the optional exam before reaching the end of the course. The teacher is a full time instructor at the "Sección de Servicios" of the School of Languages and he has been teaching English as a Foreign Language and reading comprehension in English for about 10 years.

The research team was composed of six full-time teachers at the university, one advisor and three undergraduate students from the B. Ed. in Foreign Languages. We met every week for three hours to discuss texts, to make a plan of action, to design data collection techniques and to analyse the data gathered. The different responsibilities (reading and discussing articles, collecting and analysing data, writing the minutes of the meetings and reporting the findings) were shared by all the members of the research group.

\section{Data Collection and analysis}

Data for this project were collected using different instruments, some of them designed ad-hoc, specifically for the purposes of the study. Below, we present a brief description of the instruments used:

Teacher's journal: the teacher, who is also a member of the research group, kept a journal in which he recorded his thoughts and reflections about the courses. This journal was written in English and was intended to "construct an academic view of his practice" (Bailey, 1990; Jeffrey E Hadley, 2002; McDonough, 1994 in Muñoz and Gonzalez, 2010). 
Data records in the Moodle platform: as for the web-based course, all the interactions (forums, chats, messages, workshops, exercises and results of the exams) posted on the platform were assembled and analysed by the research team in order to understand the learning strategies the students applied. All the contents of the course and the materials were presented in English.

Class observations: for the face-to-face course, two researchers were assigned to observe two classes from each unit.

Focus groups sessions: when the course had finished, four focus group sessions (Dendinger, 2000), two per modality, were conducted in order to discuss the academic experiences of the students on these courses in more depth. The set of questions prepared for these sessions covered the teacher, the contents, the platform, the exercises and the course. These sessions were conducted in Spanish.

Questionnaires: three questionnaires were designed ad-hoc specifically for the purposes of this study: a students' evaluation of the course and the teacher; a questionnaire about students' motivation and reading and learning strategies where they could describe any action they took to improve their learning process; and a students' auto-evaluation. In order to validate these instruments they were piloted before using them to collect data from the actual participants.

In-depth interviews: four in-depth interviews (Kvale, 1996; Berry, 1999) were carried out with two key respondents from each of the courses in order to validate the information gathered by the other instruments and, also, to provide individual perspectives of the courses in general. In order to select the key respondents, we chose the two students that showed the highest and the lowest motivation in each modality. The criteria to assess the level of motivation of the students was based on data gathered and analysed from the class observations, the teacher's journal and the questionnaires.

Tests: we used pre and post tests in both modalities in order to compare the progress students made in terms of the use of learning strategies. In order to analyse them, the research team hired a professor from the School of Mathematics to carry out a statistical analysis.

All the data collected were assembled and transcribed verbatim before the analysis. The analysis we carried out was essentially interpretive (Cresswell, 2007; Richards, 2005) as this is the paradigm that the research group subscribes to and we are interested in research that describes and interprets the social reality as it is perceived by people. However, for this project, we included, as mentioned earlier, pre and post tests which were analysed statistically. We need to clarify though that the data analysed quantitatively was very limited in comparison to those analysed qualitatively. For the whole project, we codified the data combining grounded and a priori approaches to establish categories and recurring themes. All the researchers independently formulated a categorization of the instruments before the meetings. Then, consensus was achieved through the triangulation of the data, using different data gathering techniques and the different perspectives of the researchers (Freeman, 1998). For the analysis presented in this article, we used almost exclusively an a priori approach as we relied for the most part on Oxford's theoretical categories of strategies.

\section{Findings}

In this section we report on the reading and learning strategies used by the two groups of students. We describe the differences and similarities found between the two groups and we draw some conclusions. 


\section{Reading strategies}

After having taught all the reading strategies explicitly in the course, it became clear that students tried to apply most of them to their process of reading comprehension. As a matter of fact, at the beginning of the course students had a very poor understanding of how to read in a foreign language that focused on syntactic elements of reading. This suggests that the only strategies they could use to understand a text were the ones from the bottom-up model as defined in our literature review. They presumed that reading a text was the same as translating it, that is the meaning of every individual word and each sentence must be transferred from L2 to L1. In this respect, Saricoban (2002, in Gascoigne, 2005) establishes some differences between effective readers and less effective readers based on the strategies they use. He states that effective readers use strategies such as prediction, deducing meaning from the context, identifying general ideas, specific information and background knowledge to get the meaning from a text. In contrast, less effective readers are more worried about knowing the meaning of individual words to help them understand the text. In our study, many of the students changed their view of reading during the course, something that was reported in greater numbers by face-to-face students during the focus groups and in-depth interviews as well as in the teacher's diary. This is evidenced in the following quote ${ }^{1}$ :

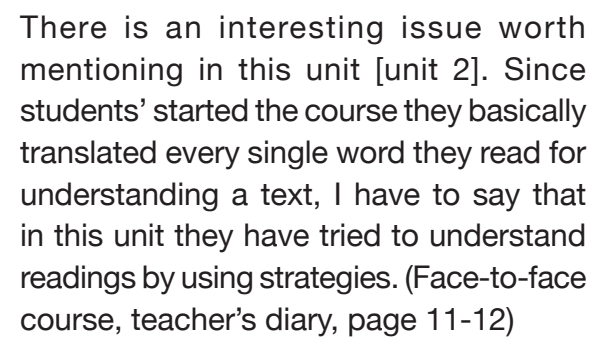

In addition to the qualitative observation of the reading strategies used by the students in both modalities, we decided to include a statistical analysis $^{2}$ to compare the grades obtained in the pre and the post test used in both courses. All the tests were designed similarly. The following tables present the results of this analysis:

Table No.3 Comparison of Grades obtained by the students in the face-to-face course

\begin{tabular}{|l|c|c|}
\hline \multicolumn{1}{|c|}{$\begin{array}{c}\text { STATISTICS FACE-TO- } \\
\text { FACE COURSE }\end{array}$} & PRE-TEST & POST- \\
\hline Number of observations & 26 & 26 \\
\hline Minimum & 2,000 & 7,000 \\
\hline Maximum & 11,000 & 10,000 \\
\hline Median & 6,000 & 9,000 \\
\hline Mean & 5,654 & 8,885 \\
\hline Variance $(n-1)$ & 5,595 & 0,506 \\
\hline Standard Deviation $(n-1)$ & 2,365 & 0,711 \\
\hline
\end{tabular}

According to the analysis, students on the face-to-face modality improved considerably during the course, as the mean increased. This implies that the face-to-face modality was effective as a mode of instruction. Concerning the web-based course, the mean decreased which does not necessarily indicate that there was not progress at all in this modality. In fact the standard deviation decreased which confirms that results were not as dispersed as they were 
Table No.4 Comparison of Grades obtained by the students in the web-based course

\begin{tabular}{|l|c|c|}
\hline STATISTICS WEB-BASED COURSE & PRE-TEST & POST- \\
\hline Number of observations & 21 & 21 \\
\hline Minimum & 4,000 & 6,000 \\
\hline Maximum & 14,000 & 12,000 \\
\hline Median & 11,000 & 10,000 \\
\hline Mean & 10,095 & 9,857 \\
\hline Variance $(\mathrm{n}-1)$ & 15,390 & 2,329 \\
\hline Standard Deviation $(\mathrm{n}-1)$ & 3,923 & 1,526 \\
\hline
\end{tabular}

at the beginning. As for this modality, several aspects must be considered: the degree of familiarity students had with the platform, the limited interaction they had with the instructor and the classmates, and the degree of motivation for the course. The data gathered indicate that the face-to-face students invested more time on the course than the web-based ones. Johnstone (1991) highlights that "there is no significant difference in achievement levels between distant and traditional learners" but there is "considerable variance in student attitudes and satisfaction levels" (cited in Sampson 2003, p.113). This was not completely the case in our study but it is clear that our group of students did not seem to be ready to work in a web-based course as a sole mode of instruction as they are not accustomed to studying autonomously and additionally, the instructor of the course did not promote other modes of interaction among web-based students. We can then conclude that it is not the modality of instruction which makes a difference on the results of students but the attitudes they have towards the modality of learning as well as the role played by the teacher. Furthermore, we can state that both groups of students achieved, as they acknowledged it, the main goal of the course which was to apply reading strategies to a text in English even if they were not yet able to completely understand it. The following quotes summarize the views of most of the students ${ }^{3}$ :
"We learned a lot of things in the course; we learned strategies to learn how to read. I think that now we are able to approach a text even if we lack a lot of vocabulary... it [the course] was very practical." (Isabela, focus group \# 1, faceto-face course, page 2) Santiago also asserted the following: "I have always had difficulties with English, and I think objectives were reached, we can read a text and say what it is about, I may not know the meaning of every word but I am able to identify the topic." (Focus group \#1, web-based course, page 10)

All of the students had a lot of difficulty identifying and naming parts of speech at the beginning of the course. Students from the webbased course said they applied their background knowledge about parts of speech in Spanish and English during the first unit. Similarly, as confirmed during the focus group sessions and in-depth interviews, the students of both modalities were unable to name the reading strategies they used, studied and learned in the course. Nevertheless, in the course evaluation and the self-evaluation, students from the webbased course reported they used pre-reading strategies such as prediction, interpreting images and graphics, skimming, scanning and identifying general ideas from a text. This is supported by the fact that most of the students asserted that units 1 and 2 were considered the most important 
to develop their reading comprehension. These units contained the strategies they can name. The reading comprehension strategies were also mentioned during the focus groups.

Concerning the face-to-face modality, the students and the teacher admitted they used their background knowledge to understand the meaning of texts, something which was not reported by students from the web-based course. Several reasons may account for the difference in the use of this top-down reading strategy. One possibility is that the teacher in the face-to-face course used readings that were related to current issues in society, something which did not happen in the web-based course where the content and activities had been previously designed and established in the Moodle platform. The teacher did not always modify the content according to students' needs although it was not impossible to do it. Some students participating in the face-toface course reported the following:

Most of the topics he [the teacher] dealt with were authentic news items so we were learning a little bit about the language and we were being informed about current affairs that we are interested in, it is like combining those two things. (Susana, indepth interview, page 4)

Another finding of this reading comprehension course in the two modalities was the transference of reading strategies. Students reported having transferred some of the reading strategies learned on the course to their reading of texts in Spanish. To this respect, Aebersold and Field (1997) found that "the unskilled reader... may actually improve L1 reading skills by having thorough training and increased awareness of reading processes in the FL." (p. 25-26). The following quote summarizes the position of most of the students:

The problem was not the platform nor the text, the problem was that we, the students ..., did not know how to read... And this fact led us to conclude that more than reading comprehension ability in a second language, we realised that we had a lot to learn about reading comprehension in general. (Julia, in-depth interview \# 1, web-based course, p. 3)

\section{Language learning strategies}

For this analysis we relied on the taxonomy of language learning strategies constructed by Oxford (1990) and in this section we give an account of the way in which students applied each one of the 6 sub-categories of the strategies. Some of them are analysed more deeply since our study is based on what we could observe from the data gathered as we did not have students fill the inventory of strategies created by Oxford.

\section{Direct strategies}

Direct strategies "directly involve the target language [and] require mental processing of the language" (Oxford, 1990, p. 37) and they are divided into three main groups: memory, cognitive, and compensation strategies.

\section{Memory strategies}

Memory strategies are those which "help students store and retrieve new information" (Oxford, 1990, p. 37). The face-to-face students associated and created mental linkages by bringing their background knowledge of the world into play when reading. This was evidenced when they dealt with texts relating to current social issues which were of general interest in the country as well as when they activated previous grammatical knowledge. One student from the web-based course asserted the following: "I think that students who had studied English before had the opportunity to recall some concepts they had forgotten. ...We used cognates, subjects, predicates... Sometimes, it was like studying 
again what we had already learned in high school or in other institutions." (Daniela, focus group \# 2 , web-based course, page 3 ).

The memory strategy related to reviewing is more evidenced in the face-to-face course. The teacher explained all the topics before doing the practical exercises, and students stated that they constantly reviewed the course material (photocopies and reading exercises). In the webbased course students were supposed to study on their own and then do the exercises although they felt freer to either read the explanations and theory first or do the exercises directly. Only occasionally did they return to the theory while doing the exercises in order to clarify some doubts.

\section{Cognitive strategies}

Cognitive strategies are defined by Oxford (1990) as those which "enable learners to understand and produce new language by many different ways" (p.37). Because of the modality of the course, the majority of students from the face-to-face course took notes of what the teacher said or wrote on the board. Students from both modalities used translation; in fact, at the beginning, they overused the dictionary to look for the meaning of words; and the online translator to translate complete paragraphs. As reported above they had the tendency to translate each individual word to get the meaning from a text. As the course progressed and as a result of instruction they started to deduce the meaning of words by analysing words in context.

\section{Compensation strategies}

Compensation strategies "enable learners to use the new language for either comprehension or production despite limitations in knowledge" (Oxford, 1990, p. 47). Students started to observe linguistic and contextual clues such as affixes, key words in titles and subtitles, cognates and transitions to get the topic of the text (the general idea) or to guess the meaning of unknown words. The teacher wrote the following in his diary:

The first topic we studied was cognate words; it was a very helpful topic as students realised that they all had a latent awareness of some basic vocabulary in English and that they could start creating meaning from those words. ... It was a kind of relief for students to see that they could actually understand some words from a text and that they could understand some ideas. (Teacher's diary, face-to-face course, page 4)

One of the points of the questionnaire which allowed us to identify the compensation strategies students used outside the class to overcome the difficulties they encountered with the texts or the workshops was related with the use of resources. This information is presented in Table 5.

Table No. 5 Resources used by students in both modalities

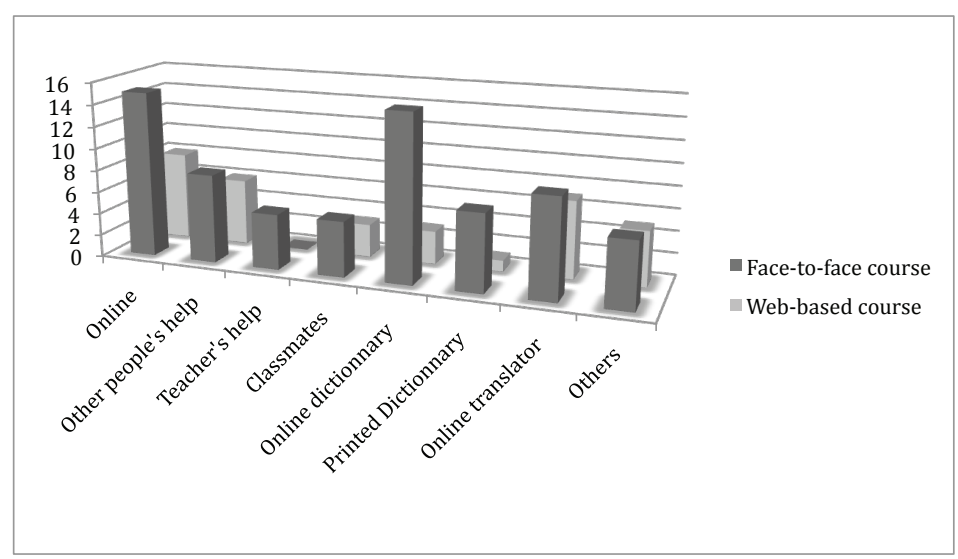


According to the information gathered and presented in Table No 5, the resources students used the most in both modalities were virtual resources such as the online dictionary and the online translator. Face-to-face students resorted to the teacher for extra explanations while webbased students looked for very little aid from the teacher. Similarly, web-based students used very little printed material. When asked about how they dealt with difficulties when doing an exercise, most of the students in the web-based course stated that they first tried to resolve the problems with the help of the dictionary or the different materials provided in the platform. If these did not help they turned to the teacher as the next resource to answer questions. As a last resort they asked for help from their classmates. When students from the web-based course compared their experience to the one in a traditional classroom, they acknowledged that in the faceto-face modality there are not the same amount of tools and resources to help the learning process. As explained above, students from the web-based course did not take advantage of the amount of resources available in the platform, which could explain the differences in the quantitative results shown in Tables 3 and 4.

Students in both modalities also turned to people outside the course for help, for example friends or even native speakers: "Everybody looked for additional resources, some used the dictionary, others the web, some students asked native speakers for help, they were useful tools to solve questions." (Miguel, focus group \# 2, web-based course, page 11).

When analysing the answers to the motivation questionnaire and during the class observations we could see that the students on the face-to-face course asked for their teachers' or classmates' help. In fact, we found that both groups of students favoured face-to-face over online support because in the face-to-face course the teacher was always monitoring the students' work and they could get immediate answers and corrections to their questions. Paechter et al. (2010) found in their study that students preferred different communication facilities, including face-to-face communication, for interaction with a tutor. When the students from the web-based modality made contact, they rarely used the forum and chat provided to interact with classmates and the teacher; e-mail was used instead. Paechter et al. (2010) support this view by arguing that students appreciated the instant exchange of information when using online communication, e.g., the possibility of obtaining fast feedback about assignments. We realised that students from the web-based modality were afraid of writing in the forum of the platform in English because they were not confident with their English writing skills and did not want to be exposed in front of their classmates. As they thought they were expected to write in English, their participation in the forum was very limited and they preferred to write e-mails which were written directly to the teacher. As for the face-to-face course, class observations allowed us to note that team and pair work was encouraged by the teacher which did not happen in the web-based course.

\section{Indirect strategies}

As stated by Oxford, indirect strategies "support and manage language learning without (in many instances) directly involving the target language" (1990, p. 135). Among these strategies Oxford lists metacognitive, affective, and social strategies.

\section{Metacognitive strategies}

Metacognitive strategies "allow learners to control their own cognition-that is to coordinate the learning process" (Oxford, 1990, p. 135). Face-to-face students planned and arranged their learning, for example they sought out opportunities to practice. In the motivation 
questionnaire they stated that they watched movies or news with subtitles in English, they read newspapers or small, basic texts to try to apply the strategies they had learned in the course.

One difficulty reported only by students from the web-based course was that of time management, which shows the lack of planning for their learning tasks. In fact, the data recorded in the platform shows that the periods of time students had to do the exercises were very different, varying from a few minutes to whole days. The platform also allowed us to find out that most of the students did the exercises at the last minute, that is, at the deadline or the day before. In addition, students complained all the time about the large amount of work that the course required. Students highlight flexibility with regard to time as one of the benefits of distance learning. Although the web-based course was very time consuming, they had the opportunity to manage their time according to their own needs since they did not have to go to class twice a week which would have affected their busy professional life. The following quote summarizes the view of most of the students in the web-based course:

The web-based distance course is excellent for us regarding time because we are people who work, we have very busy schedules, in my case, I work from six in the morning to six in the afternoon, twelve hours, I do not have time to attend a course anywhere. It's very practical, I can get home and have access to the platform anytime. (Julia, web-based course, focus group \# 1, page 4)

\section{Affective strategies}

Affective strategies, according to Oxford, "help to regulate emotions, motivations and attitudes" (1990, p. 135). At the beginning of the course most students claimed to lack confidence with their English. Their limited communication skills in the foreign language caused some tension that was overcome as they did the exercises and understood the topics. As for their confidence in class, students recognised that the way the course was organised allowed them to build their confidence since the level of difficulty of each text increased progressively.

One further aspect we would like to bring to your attention concerns assessment and evaluation. These became issues in both courses because of the apprehension students felt towards graded activities. Unannounced, assessed workshops done in class were very stressful for the face-to-face students who even complained because of the impact that failing this compulsory course could have on them. The face-to-face course allowed the teacher to provide feedback during the class, which helped students to decrease their anxiety levels. However, in the web-based course the feedback was not provided immediately after the students completed tasks, thus their anxiety levels were quite high, and they were always concerned about their performance, not only in the tests, but also in the work assigned for the course. In this respect, Hakkinen (1994) affirmed:

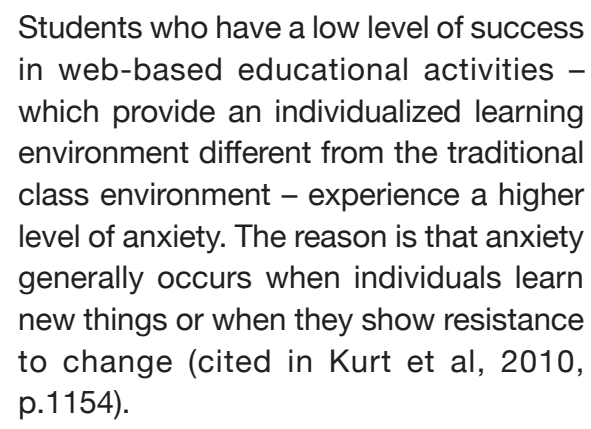

The anxiety was particularly evident when students from the web-based modality got automatic grades given by the platform. In fact, some of the assignments were not graded by the platform but by the teacher, these were called the manual exercises. When submitting these exercises, the platform gave a grade of 0.0 while 
waiting for the teacher's mark. This caused a lot of stress but students felt less stress and tension as the course progressed. Students participating in the face-to-face course were not afraid of English anymore, mainly because of the class atmosphere and the support and confidence the teacher gave to them. Students who took the webbased course also reported having gained selfconfidence during the course since they had to rely more on what they could find and understand themselves to answer the reading comprehension questionnaires and do the exams.

\section{Social strategies}

Regarding social strategies, the ones that "help students learn through interaction with others" (Oxford, 1990 , p. 135), both groups of students resorted to the teacher to ask him questions to solve content or technical doubts. Face-to-face students did it directly in the class and the others did it through e-mail, they participated very little in the chats and the forums because of their lack of time and barely interacted with their classmates. Most of the questions they asked were about technical difficulties with the platform or about the grades.

Students following the face-to-face modality preferred group to individual work for tackling workshops and activities, sometimes it was because the teacher promoted such cooperation but most of the time they formed groups spontaneously. Some students from the webbased course also expressed the need for personal contact.

\section{Limitations of the study}

We identified a significant limitation of this study that needs to be tackled in future projects. It concerns the theoretical models we have used to approach reading. We are particularly aware that our perspective to reading has been essentially cognitive and that some other models of reading have not been studied in depth. This comes from a tradition at the School of Languages where these courses have concentrated exclusively on the teaching of reading strategies and have been taught face-to-face. We lack expertise in teaching web-based courses and for this reason we are aware that we are strongly influenced by reading printed texts and by the methods that have been used in face-to-face modality. The "Sección servicios" should continue studying the new online literacies in order to improve the teaching of reading through ICTs.

\section{Conclusions and further implications}

Students from both modalities changed their perception of reading comprehension from the view that the reading process was a matter of translating every word to the concept that the main ideas can be deduced by means of the reading strategies promoted during the course. Students not only applied reading strategies which were taught explicitly but also language learning strategies that, although not promoted explicitly in the course, derived from the learning process itself. Concerning the web-based students, sometimes the feeling of isolation was a source of frustration, particularly in relation to the grades the platform gave to some of the exercises.

We could say that most of the students were not motivated to take the course or to learn English as the course is a requirement of the university and they do not see the need to use English in their professional lives. Some of the students chose the web-based modality because they believed it was easier, they would spend less time doing the activities and they would have the opportunity to organise their time. Others chose the face-to-face modality because they felt more comfortable with the personal contact even if they knew that they would be tired after a long day at work. Some of them admitted that they would not have taken the course if it had not been a requirement. Biviana from the web-based course asserted: 
I have never liked English, I took the course because it was a requirement, and I maintain this view, that it is not my thing, and I do not want to keep on studying it. If I see a text in English l'd rather not read it, not even look at it, I do not like it ... I have the requirement, I liked the course a lot, but that's the end of story. (Focus group \# 1, web-based course, page 17)

Even if they were not willing to take the reading comprehension course some of them were eager to do extra activities to learn and practice English, but it was mainly because of the instructor. All the students acknowledged him as the main motivating factor in the course. The face-to-face students considered that the contact with him was really direct and personalised. As for web-based students, they highlighted his constant support throughout the course although they had not met him personally.

As mentioned earlier, some students attempted to take the reading comprehension exam so that they could abandon the course because they were not eager to invest all the time that the course demanded. In the web-based course, eight students obtained the passing grade in the exam and dropped the course. Similarly, one student obtained the grade in the face-to-face course. This study gave us some evidence that for many students in the School of Law, these courses should not be a requirement. However, to substantiate this claim more evidence need to be gathered. This issue has been a concern of the group of teachers working at the "Sección servicios" who question the requirement of foreign language reading comprehension for all the students of the university. They are currently working on a new project where they intend to evaluate the program and the policies the university has concerning the proficiency in a foreign language that has had severe effects on both teachers and students at the university.
Thanks to this project, we redesigned the reading comprehension course offered in the web-based modality. In the new course the units were not organised based on the strategies but on different thematic units where reading strategies are taught to facilitate the understanding of the content. As evidenced in the analysis of the data, we consider that both modalities are appropriate to teach reading comprehension to graduate students. However, the web-based modality requires students and teachers to have an additional awareness of new literacies and ICTs. One of the outcomes of this project was a methodological guide we elaborated to teach reading comprehension to graduate students at the university. In this document we present a set of guidelines and suggestions that should be considered when teaching in both modalities. In addition we suggest a new modality that could be implemented at the university: blended learning, in which some elements of face-to-face and webbased modalities could be mixed (Bartolomé, 2004). This is an upcoming project for the "Sección servicios". We have not elaborated further the effects these modalities have on graduate students as this was not the purpose of the particular part of the study we presented in this article.

\section{Acknowledgments}

We are deeply thankful to the blind reviewers of this article. Their comments helped us improve its quality.

\section{REFERENCES}

Aebersold, J. A. \& Field, M, L. (1997). From reader to reading teacher. Cambridge: University Press.

Alyousef, H. S. (2005). Teaching reading comprehension to ESL/EFL Learners. The Reading Matrix, 5 (2), 143-154. 
Anderson,N.J. (1999). Exploring Second Language Reading: Issues and Strategies. Boston, MA: Heinle \& Heinle.

Ardila, M. \& Bedoya, J. (2006). La inclusión de la plataforma de aprendizaje en línea MOODLE en un curso de gramática contrastiva español, inglés. Ikala, $11,181-205$

Bartolomé, A. (2004). Blended learning: conceptos básicos. Píxel-Bit. Revista de Medios y Educación, 23, 7-20

Berdugo, M. \& Pedraza, N. (2008). Evaluación de Lingweb: ambiente virtual para el aprendizaje de lenguas. Lenguaje, 36, 473-509.

Berry, R. (1999). Collecting data by in-depth interviewing. Paper presented at the British Educational Research Association Annual Conference, University of Sussex at Brighton, September 2-5, 1999. Retrieved on September 9, 2011 from http://www. leeds.ac.uk/educol/documents/000001172.htm

Brown, D. (1994). Teaching by Principles: An Interactive Approach to Language Pedagogy. Englewood Cliffs,New Jersey: Prentice Hall Regents.

Creswell, J. (2007). Qualitative inquiry and research design: Choosing among five approaches (2nd ed.). Thousand Oaks. CA: Sage Publications

Dendinger, M. (2000). How to organize a focus group. Meetings and conventions. Retrieved on September 26, 2011 from: http://www.meetings-conventions. com/articles/how-to-organize-a-focus-group/ c10136.aspx

Facundo, A. (2004). La educación superior virtual en Colombia. In Asociación Nacionalde Universidades e Instituciones de Educación Superior, La educación superior virtual en América Latina y el Caribe (pp. 175-222). México: ANUIES.

Freeman, D. (1998). Doing teacher research: From inquiry to understanding. Newbury House: Heinle and Heinle.

Gascoigne, C. (2005) Toward and understanding of the relationship between $\mathrm{L} 2$ readingcomprehension and grammatical competence. The Reading Matrix, 5 (2), 1-14.

Galindo, L. (2002). Elementos que interactúan para la educación: presencial, presencial a distancia y la virtual. Retrieved on September 26, 2011 from: http://bibliotecadigital.conevyt.org.mx/colecciones/ documentos/somece2002/Grupo3/Galindo2.pdf
García, L. (1999). Historia de la educación a distancia. Revista Iberoamericana de Educación a Distancia, 2 (1), 8-27.

Grabe, W. (2007). Reading in a second language: moving from theory to practice. USA: Cambridge University Press.

Grabe, W. \& Stoller, F. (2002). Teaching and Researching Reading. Harlow, Essex: Pearson Education Limited.

Johnstone, S. (1991). Research on telecommunicated learning: Past, present and future. The Annals of the American Academy of Political Science, 514, 49-57.

Kurt, A., \& Gürcan.A. (2010).The comparison of learning strategies, computer anxiety and success states of students taking web-based and face-to-face instruction in higher education. Procedia Social and Behavioral Sciences, 9, 1153-1157

Kvale, S. (1996). Interviews: An introduction to qualitative research interviewing. London: Sage Publications.

Leu, D. J., Coiro, J. Castek, J., Hartman, D. K., Henry, L. A., \& Reinking, D. (2008). Research on instruction and assessment in the new literacies of online reading comprehension. In C. C. Block, S. Parris, \& P. Afflerbach (Eds), Comprehension instruction: research- based best practices (2nd ed.) (pp. 321-346). New York: Guildford Press.

Leu, D. J. Jr., Kinzer, C. K., Coiro, J., \& Cammack, D. W. (2004). Toward a theory of new literacies emerging from the Internet and other information and communication technologies. In R. B. Ruddell \& N. Unrau (Eds.), Theoretical models and processes of reading (5th ed.) (pp. 1570-1613). Newark, DE: International Reading Association.

López, A. \& Giraldo, M. (2011). The English reading strategies of two Colombian English pre-service teachers. Ikala, 16, 45-76

Merriam, S. (1998). Qualitative research and case study applications in education. San Francisco, CA: Jossey-Bass.

Muñoz, J.H \& Gonzalez, A. (2010) Teaching reading comprehension in English in a distance web-based course: new roles for teachers. Profile, 12, 69-85.

Nuttall, C. (1996). Teaching reading skills in a foreign language. Oxford: Heinemann.

O’Malley, J. M. \& Chamot, A. (1990). Learning strategies in second language acquisition. Cambridge: Cambridge University Press. 
Oxford, R. L. (1990). Language Learning Strategies: What Every Teacher Should Know. Boston, Massachusetts: Heinle \& Heinle Publishers.

Paechter, M. \& Maier, B. (2010). Online or face-to-face? Students' experiences and preferences in elearning. The internet and higher education, 13, 292-297.
Richards, L. (2005) Handling Qualitative Data: A Practical Guide. London: SAGE Publications.

Sampson, N. (2003). Meeting the needs of distance learners. Language learning \& technology, 7, 103-118.

Yin, R. (2003). Case Study Research: design and methods ( $3^{\text {rd }}$ ed.). Thousand Oaks, CA: SAGE Publications.

\section{Appendix \\ Consent form used in the study}

Yo, identificada(0) con cédula de ciudadanía número

de informo que mi participación en el proyecto de investigación "Efecto de las modalidades de instrucción presen-

cial y virtual en la comprensión de lectura en inglés en los posgrados de la Universidad de Antioquia" es de carácter absolutamente voluntario. Este proyecto es coordinado por el grupo de investigación EALE (Enseñanza y Aprendizaje de Lenguas Extranjeras) perteneciente a la Escuela de Idiomas de la Universidad de Antioquia. Así mismo, doy mi consentimiento para que toda la información que brinde sea grabada y utilizada sólo para propósitos investigativos.

Firma

1. All the testimonies were translated by researchers since the interviews and focus group sessions were carried out in Spanish. The journal the teacher kept was written in English.

2. The statistical analysis was made by Catalina Cortés who belongs to the Department of Mathematics from Universidad De Antioquia.

3. In order to protect participants' identity, we use pseudonyms in this text.

\section{THE AUTHORS}

FABIO ALBERTO ARISMENDI GÓMEZ . Holds a B.Ed. in Foreign Languages from Universidad de Antioquia and a M.A. in Language Sciences from Université Stendhal, Grenoble III. He is a full time professor at the School of Languages of Universidad de Antioquia and a member of the research group "Enseñanza y Aprendizaje de Lenguas Extranjeras" (EALE).

DORIS COLORADO LÓPEZ. Holds a B.Ed. in Foreign Languages from Universidad de Antioquia. Currently, she works as a professor at the School of Languages of Universidad de Antioquia and she is a member of the research group "Enseñanza y Aprendizaje de Lenguas Extranjeras" (EALE).

LUISA FERNANDA GRAJALES MARÍN. Student from the B.Ed. in Foreign Languages at Universidad de Antioquia. She is a member of the research group "Enseñanza y Aprendizaje de Lenguas Extranjeras" (EALE). She currently teaches English to children and adolescents at the extension center at the School of Languages of Universidad de Antioquia. 